University of Rhode Island

DigitalCommons@URI

Open Access Master's Theses

1967

\title{
The Interrelationship of Bulk Density, Granule Density, Tablet Weight, and Weight Variation
}

Amritkumar Bhandari

University of Rhode Island

Follow this and additional works at: https://digitalcommons.uri.edu/theses

\section{Recommended Citation}

Bhandari, Amritkumar, "The Interrelationship of Bulk Density, Granule Density, Tablet Weight, and Weight Variation" (1967). Open Access Master's Theses. Paper 180.

https://digitalcommons.uri.edu/theses/180

This Thesis is brought to you for free and open access by DigitalCommons@URI. It has been accepted for inclusion in Open Access Master's Theses by an authorized administrator of DigitalCommons@URI. For more information, please contact digitalcommons-group@uri.edu. 


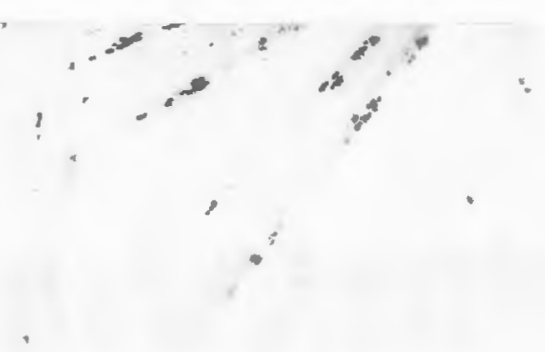

\section{$\checkmark \quad$ ABSTRACT}

The effecta of granule density and bulk density on tablet weight, welght variation, and tablet density were determined for tablete compressed on a Colton Model 216. rotary tablet press. Hardnes, thickness, and disintegretion times were aleo determined for the tablets produced. Standardized granulations were made from lactowe and axtures of 1 sotose and biamuth subcarbonate, with gelatin as a binder. Granule density and bulk density of the granulations were varled by changling the concentrationg of blamuth abcarbonate in the formula. All tableta vere mede at a flxed rate of tableting using standardized settings of the 1112, pressure, and overloed adjotments. The interrelationghip between granule denelty and bulk density was found to be almost Inear, as was also the relationship between granule density, bulk density, and tablet weight. 


\section{MASTER OF SCIBTOE THESIS}

or

AMRIFKUMAR HAIDARI

\section{Approved:}

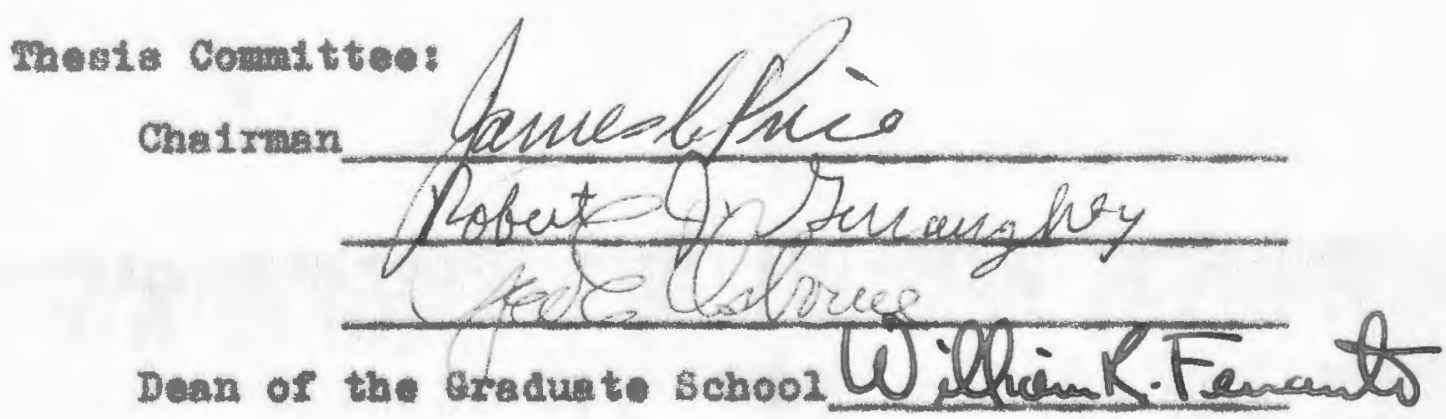

URIVERSITY OP RHODE ISLAZD 
PABLE OF CONTEYAS

\section{CHAPTIR}

1. IHTRODUCRIOX ....................... 1

II. REVIEW OF PREVIOUS ITTMARURE . . . . " . " 5

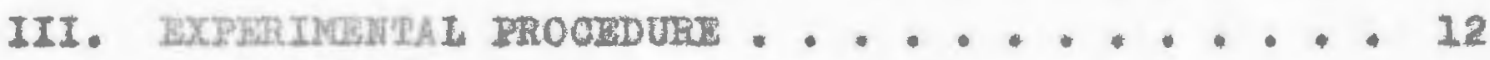

General Order of Exporiuente......... 12

Prollatum Exporimeate to Peat Appl1cabl11ty

of Itterature Iat. .............. 13

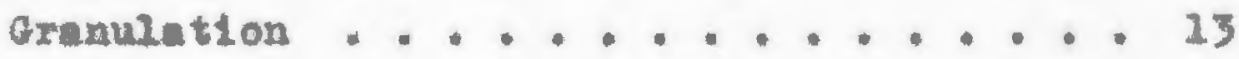

Preparation of Stroh Solution....... 13

Preperation of Granulea ........... 14

Iubrteation ................... 15

Tablet Corpreaton .............. 15

Granule Sia Experingate .......... 15

Tabletiag Rate Ixperinonte......... 16

Comprecelon of 16 Mebh Granules . . . . . 16

Conpreselon of 20 Keen Granulee . . . . 16

Erfoet of Die size ............... 17

Cranule and Bu2t Done1ty Brperineats ..... 17

Preparation of Granules .......... 17

Nethod of Verietion of Denesty of Cramulea. 18

Preparation of the Dinder Solution..... 18

Mulne ........................ 18

Aranulatlor ................... 18

Soparation Into $\$ 180$ Prectione ........ 20 
Determination of the Pertinent Charecter-

1stics of the Granulations........20

Size Diatribution Determination ..... 20

Bulk Density Determination........ 21

Granule Denaity Datormination ...... 21

Compresaion of armules ........ 23

Equipreat .............. 23

Selection of Operating Parmetarg ... 23

Iubrication ............. 23

Deternination of Tablet Charecterietios . . 24

We1ght................ 24

\$120................. 24

Herdnes: .............. 24

Diatutegration Hine ........ 25

IV. RHSULTS AMD DISCUS\$ION ........ 26

Preliminary mertmenti ......... 26

Granule Geracterist1c ........ 26

affect of Granule s1ge ....... 26

Effeot of Pableting Size......... 28

gffect of Die Dlanter......... 30

Interrelationship of Granule Density, Bulk

DenoLty, Tablet Welght and Welght

Teriation .............. 33

Cheractertistica of Grenulations .... 33 
\$1ze Distribut1on ............. 33

Bulk Density .............. . 36

Granuze Dang1ty .............. 36

Miscellaneous ................ 36

Relationald of Bulk Denelty to Granule Density 41

Interrelationabip of Tablet Weight, Granule

Density. Bulk Density and Welght Varlation . 43

Cheraoteristios of the Tableto Produoed from

the Different Granulations . . . . . . 49

У. SUMMRY AND CONCLUSTONS . . . . . . . . . . 53

RERERTRCRS . . . . . . . . . . . . . . . . 55 


\section{LIST OP TABLES}

TABLE

PAGE

I. Granulation Formulas ................

II. Tablet Welght and Coefficlent of Varigtion obtalned From 3 Different stses of Granulat1ong .......................

III. Average Welght of Tabletg Prom No. 16 and No.

20 sleve Granules, Obtalned at Different Speeds ......................

IY. Effect of Die S1ze - Avarage Welght and Coefflelent of Variance of rablets...... 34

7. Plain Lactoa Granulation \#26 Mesh Diameter

Count ..................... 35

VI. Granulation of Iactose and Biamuth SubCarbonate Particle Dianater Count ........ 39

VII. Granule and Bulk Denaity of Different Gran-

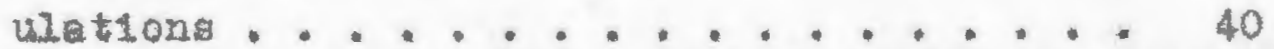

VII. Effecti of Granule and Bulk Density on

Tablet Weight and Welght Variation ..... 45

IX. Table Showlng Other Data on Pableto Produced . 52 


\section{LIST OP PIGURES}

FIGURE

PACE

1. Heroury Displacement Apparatus to Determine

Granule Dens1ty .................. 22

2. Effeot of Tableting Rate on the Arerage Welght

of Tablets frow No. 16 and No. 20 Steve

Granulations .................. 31

3. Effect of Tableting Rate on Average Welght of

Pableta from No. 16 and No. 20 SLeve Granules . 32

4. Granule S1ze Diatribution of Plain Iactose No.

$16 \$ 120$ Granules ............... 37

5. Granule S1ze Distributions of Lactose - Bismuth

Suboerbonete Ho. 16 Granules ......... 38

6. The Reletionohip of Blsath Suboexbonete

Conoentration to Granule Density . . . . . 44

7. Effect of Granule Denalty on Average Welght of

Tableto.................. 47

8. Bffect of Bulk Dena1ty on Arerage Welght of

Tablets.................... 48

9. Relationship Between Granule Density and Bulk

Denetty . . . . . . . . . . . . . . 50 


\section{INTRODUCTION}

The compressed tablet haw become one of the most widely aocepted dosage form for the adnintatration of orally effective therapeutio agents. It provides convenient and, If well made, an effletent form of molid dosag for oral adminlatration. The edrantages of this type of pharmaceuticel preperation are well knom and 1nclude accuracy of dose, econony, stab1lity, portab1lity, concentration, legance, and convenience in diepenoing and shipping.

The invention of compressed tablets 1s usuelly attributed to Brackedon, who in 1843 obtained an Baglish petent on a lmple device for compressing dry powder. By 1874 tablete for almost every known disease were belng sold on Iuropean and American markets. At one time the preparation of tableta was based more on empirical conalaerations than on sound scientific principles. In recent years, however, there has been a trend to move frow the 'art' in making tableta toward the sclence of tebleting. Tablets firat became official in the gat revision of the United Stetes Pharmacopela, 1926, and have been offletal in each aucceeding revision.

The Hetlonal Formulary has included an increasing 
number of tablet. ince thelr introduction into NP $V$ in 1926.

Both the United States Pharmecopeie and Natlonal Pormulary set certaln gtandards for the tablets lieted therein, lneluding:

(1) Identity and purity of active ingredientis

(2) Quant1tetive 11mits for the active ingredients

(3) IInits on diatutegration time

(4) Itaits on valght variation.

of these four atendards for good tablets, the flrst two are malniy applicable to the purtty and phyalcal-chemical otendards of the Ingrediente to be used for the required theraputic action from the tobleta. The tanderds for disintegration time lint wolght of tablet are of great importance in the formulation and compression of granules in the preparation of tablet: a dosege forms.

Mo materials can not be made into tablets drectiy, but wust be granulated; that 10, they mat be made Into granules before they can be succesarully compreased. The oharecteristics of the granulation such as granule size, bulk deneity, granule density, and porosity all have a direct effect on the tablets produced.

The qualities of the Ilnished tablets are Influenced by the physical and chenical properties of the granulations, 
which, In turn, depend upon the physloal properties of the Ingredinte used to ake them, Theae propurtles, e. g. denaity, w11 most Ilkely not be the same for enoh 1ngredlent belng ued; and the density of Eranules prepared from auch a vartety of ingredients vil1 not be the game for different type of tablet formulatiane. Marefore, overall granul density of different tablet formulations w111 change from one to another, and these varlations should heve aone measurable effect on the welght of tablets prom aced. In addition, the bulk dene1ty is relatod to grenule denstty: therefore. 11 granul dengt by w11 vary from one granulation to another, the bulk density w11 also vary. The character or qualitios of granules are influenced not only by the materials golng lnto the granulation but aleo by the technique of manceture of the granulation. A granulation made largely from bigmuth subcarbonate (density $6.86 \mathrm{gm} / \mathrm{cc}$ ) is 11kely to have bigher bulk density and hlgher granule denalty than one contalning largely onlelum carbonate (dena1ty $2.92 \mathrm{gu} / \mathrm{cc}$ ). In addition, a granulation wth a wide range of granule olzes and a large proportion of "Ines" is I1kely to have a blgber bulk dens1ty than a grenulation with a narrow granule size dictribution.

Since, during the compreasion of a particular granulation, the welght of a tablet is adueted by rarying the rolua of the die carlty, the packing characterigtics of a 
granulation are importent. If the die cavity in the operating tablet machine is I1lled by predominently large granules, there will be large rold speces. But if the same die carity is filled by emaller granules, the space will be more compacty filled and there wil be less vold space. The tablets compressed from the two granulations wil not bave the same weight. Thua variation in the granule size ultimately may cause variation in the velght of tableto. The effects on tablet we1ght of the rariables of granule size, granule fluidty, punch and dis sie, tablet base formula, and tableting opeod heve all been studied and reported in the 11terature. However, there appears to be no report in the 11terature concerning the effects of the variables of bulk density and granule density on tablet weight. Since the welght or dose of medication in tablet ultimately depends on the volume of granulation entering a die carity, it is obrious that the density of the volume of granulation meaured out by the machine wll influence the finel welght of the teblets produced.

This etudy 1s, thorefore, privarily concerned with the relationship of the quality of density, including bulk density and granule density, to tablet weight. Sinoe bulk density and granule denoity are interrelated, and aince tablet weight varietion is an important ajunct to tablet welght, these relationships are also considered. 


\section{REVIBW OF PREVIOUS IITERATURE}

Variation in the weight of compressed tablets was reported in the pharmecut1cal 11 terature as early as 1926; in this study Liveraeege (2), an Ansiylat of Blrainghas, Fingland,examined forty-two saples of $5 \mathrm{graln}$ tablets of four different kinde, lncluding codiun salleflete, esplrin, calclum lectate, and sodium cltrate. Ho analysed more than 1700 Individual tablet to deternin the uniformity in velght of the tablet: uniformity in the amount of medicinaly active substanee, and uniformity in disintegration time of tublets. He found that the weight of 91.8 per cent of the tablets did not vary more then 5 per cent from the mean veight of the tableto of the sample; 7.3 per cent of the tableta ranged from 5 to 10 per cent from the mean; and 0.9 per cent mowed a deriation of greater than 10 per cent from the mean wolght of tablets. Based on h1s observations of the average velght of tableta, he suggested that, "It 1. necesaary thet the mixture (1.0. granule mixed with talcum, tarch, stc.) should be in a unfform state of dir1sion, or equel volumes will not correepond to the equal welghts, and therelore some tablets will veigh more than otbers." In this roport he did not pin point any other factors causing weight variation, but stated only that the 
granulation should be of uniform size. It bas been only since 1948 that further detalled investigations of tablet unfformity have been reported. Arambulo and Deardorff (4 and 5) studied weight variation in tablets, using godium chlorlde a besic granulation. In this atudy, sodium chlorlde grenules were sepereted into narrow glze ranges from 4380 to 81 mierons and comprensed into tebleta on single punch tablet preas. The press adjutaonts were sot and remalned constant euring the compression of all the tabLets.

Thee workers found thet, as the purticle aize decrensed, the average teblet weight at firat increased, reaching aximum at 150 - 350 microns, and then decreased. They also found that, as the particle size decreased, the percentage of physically perfect tablots increased, the tablets became more glossy, and in general more batisfactory. Thig trend also passed through a maximum, followed by production of trblets decreasing in vality.

Akol and Fukuda (9), two Japanese woricera, have studled oeveral factors cauling variation in the weight of tib10ts. In on paper they reported a etudy of the relationahipe between both granule sise and teblet diameter and tablet welght variation. Their conclusion on this aspet of the invertigation was, "In tebleting of tablets of a definite size, the larger the diameter of granules, the larger beoane 
the velght variation, the ratio of 1 to increase being ilnear and in tableting of tablets of different was with the granules of the same olse, [the] greater the weight of tablets [th] gmallex became the weight variation, the ratio of decratee belng linear."

In order to sudy the relationship between the fluldIty of granules and velght variation of tablets during tableting $(8 ; 11)$ these same workers coated the granules with Veseline, thereby producing granules of different fluidity. They found that the greater the coefficlent of friction of the granulea, the greater becones the welght variation. The coefficlent of static frietion was found to increse th Increasing amount of powder (Inoluding lubricant) in the granulea. From their reaulta they concluded that it seems advantggeou to have the granules as small as posatble. They also studied the influence of number of different Iubricants, Inoluding potato aterch, Carbowax 400 , tearle acld, Borlc acid, talcum, megnesium tearate, calclum atearate, lycopodium, and cloroall on the otatic frlotion coefflolent. From this study they conoluded that the lubricant powder effects decreas of the coefficiont of tatio friction of aticky granules, but such abtlity differs with different grades of lubricant. They suggested that it would be usefur to measure the static friction coefficient of granules in oheoking the quality of betches of granules in 
plant production.

Raff, Arambulo, and Deardorlf (10) have elso reported veight veriation in tablets in tbelr study of internel flow of granulation durling compression. They used statistical quality control charte for tablet welght, hardness, and compressional presaure as an aid to study the internal flow of granulation in the single punoh tablet preas.

In their study they used lactose-starch, godium chlor1de, and apirin-iactose-starch granulations. The granulations were prepared by a wet granulation method using starch paste as a binder. In the case of the lactoso-starch granulation, granules were pased through a U. S. Standerd S1eve \#10 and retalned on a \#50. In the case of the aspirin-lactose-starch granulation, aspirin was pesed through a \#70 sieve and retained on a \#100, and 1 wa mixed with lectose-gtarch granulation. In the cese of sodium chlorlde, two collections were made; one granulation wes pessed through a $\# 10$ gleve and retained on $\# 12$; the other was pased through \#45 sleve and reteined on \#50. Talc and magnesium stearate were used as lubricanta for all granulationa. Compresalon was carried out in the tokes Model E single punch tablet presa, using 11/32-inch punches. The speed of the machine was adjusted to produce approxinately 100 tablets a mute. 
In this study these workers found that, during the firat part of the run, the weight of the tablets usually Increased, but sometines decreased, depending upon the nature of the granulation. In the case of the apirin-lactose-starch grenulation a subetantial decrease in the weight of the tablets was observed. Reaults of atudies in other flelde indicate that, in order to avold too rapld a Now of fines through coerser particles and consequent variation in veight of tablets, one should not have too wde disparity in particle size, and further, the active ingredient should be of such a size a to fill subtantially the average vold space of the basic granulation. They also point out that their experimonts confirmed the usual belief thet it is Important to check the tablet welghts most closely during the first and last querters of the run.

Hasegawa (12) has reported a study on tablet weight varlation in wich be considered four factor causting woigbt variation in tablets. The four factors studied were:

(1) the effect of three different tablet bases;

(2) the effect of punch diameter $(7 \mathrm{~m} . \mathrm{m} ., 10 \mathrm{~m} . \mathrm{m}$. , and $13 \mathrm{m.m}$. dlemeter punches);

(3) the effect of granule size (lieve size No. 12, No. 14 , No. 16, No. 18 and Ho. 20); 
(4) the effect of speed of tableting (42 tablets a minute and 76 tablets minute).

The study was conducted using a Kimura Model KT2 tablet press. Potato starch was used as a binder, and $2 \%$ talcum was used as a lubricant.

From the reaulte obtalned during this study, he concluded thet:

(1) slgniflcent differences were not recogniged among different tablet beses;

(2) reduction of punch dianoter increased welght variation of tablets quedratically;

(3) reduction of granule elze decreased welght variation of tablete, and the relationehlp wa linear; the degree of decrease of welght varition was different for each punch;

(4) significant differences were not recognized between the two tableting rates 1.a. 42 and 76 tablets a minute.

Untformity of drug domage in compressed tablets was studied by Moskalyk, Chatten, and Pernarowski (14), who welghed ent assayed indipldual tablets in order to determine the actual variability in drug dosege. The variations in potency found in a batch of tablets were as a rule greater than those indicated by the uniformity of weight test. Deviationg were found greatest in the lightegt 
weight tablets within a batch. These investigators believe that, should tbis prove true for all tablets, then a test based on the anelysis of a small number of lightest weight tablets or groups of tablets could be adopted as a control procedure to sssure uniformity of drug dosage. Used in conjunction with the uniformity of weight test, it would provide a more effective control over excesive dosage variability in tablets. 
EXPERIMTENAL PROCEDURE

\section{Genurel Order of Exnorinunte}

Prelininary experiments were cerried out to estab11eh whether concluaions from previous work could be applied to the tableting set-up arailable for testing the bypothasis that tablet welght and welght variation io related to granule density and bulk denelty of granules. Tous, in the flret sertes of experimonts, the effects of granule size, tableting reto, and die alse on tablet velght and welght variation were otudied and the reaults comptared with those in ilterature. The results of these experiments allowed the selection of a norwal operating region for further experinents concerning the main object of this thesie, i.e., the interrelationahip between granule density, bulk density, teblet velght, and welght var1ation. In the controlled density experimentag density of a basic grenuletion was raried by the addition of blemuth subcarbonate; the alze of granuleo wa controlled within a nurrow range; bulk and granul donalty were detervalned, and the relationahipa among tablet weight, weight vartation, and granule-bulk denalty were found, by compreasIng the grenules on rotary tablet machine uling the same mechine settinge for all the grenuletions. 


\section{B. Preliminary Experiments to Test Applicability of the}

\section{Iiterature Deta}

The following preliminary experiments were carr lied out to determine the applicability of the literature deta.

(1) Granules of three different aieve alges were compreat on the tablet machine, malntainting conatant speed of mechine, preseure efection, capnotby, ete.

(2) Speod of the tablet machine was Inoressed, keeping preasure and capactiy settinge constant.

(3) Two sets of standard conotve dies and punches $\left(3 / 8^{n}\right.$ and $\left.3 / 16^{n}\right)$ were uaed on the tablet chine; the other sottlags were kept contant durlug tablet compression. Grenuletion. The general formula for prepertigg granulea

$$
\begin{aligned}
& \text { Lactose USP .... } 300.0 \text { gma. } \\
& \text { stareh 502n. } 5 \% \text {.. } 650 \text { ml. }
\end{aligned}
$$

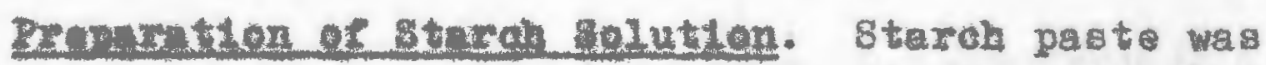
used a binding agent to form the granulation. Commerolally avallable corn tarch, $50 \mathrm{gms}$, was put in a sultable contalner, one liter of cold water was added to it slowly, and wh oontinueus atiring to arold the formation of 1uaps. Phis mixture wa sowy heated wth continuous tirring, until the volution began to boll and a tranelucent peste resulted. 
Prenaration of Granules. The welghod amount of lac tose wa placed in a Hobart mixer and starch peste was added graenelly to the oontente of the mixer while the mixer we rotating. Starch pate wes alowly added and the mixture st1rred until the mass readly cohered to a ball but qually readily broke up when rubbed between the fingora. Th1s damp maas was then taken out of the wixer and granulated wh an Frwoka" wot granulator. The wot granules were colleoted on brow paper, put on trags, and flnally dried in an oven at $70^{\circ}$ for four hourg.

The dried granules were then raduced to a smaller alzo ualng an Erweke dry grenulator and weparated uelug 0. S. Standar No. 16, 20 and 40 sieves. The granules referred to as \#16 mesh were passed through a No. 16 Standard sieve and were rotained on No. 20 sieve. In the case of 20 mesh granules, all granules were pasaed through a No. 20 and were retalned on a No. 40 sieve. In the case of Mo. 40 granulew all granules posed through 40 oleve and were retalned on * 60 sieve. The granule and buzk densitios were determined. (Ste III C - granul and bulk density axperimenti.)

*Hobart Manufecturing Company, Troy, Ohlo

*Erewka G.M.B.H., Pranirfurt. Distributor Chemical and Pharmaceutical Industry Co., Inc., 90 West Broadwey, N.Y.C., Now York. 
Lubrication. All grenuleo wore Iubricated wth $0.5 \%$ magnesium atearate prior to compreselon.

Tablet Compreasion. \& Colton Model $216^{*}$ rotery tablet prees was used for the compression of all of the granulationo. The settinge and operating conditione for the compression of each granulation lot were varied in order to control certain veriables,

Grenule s1ze Brperimente. In order to tudy the offecte of granule eize on tablet welght and wolght var1etion, three alfferent sizes of grenules prepared and oepareted were used. Threo-olghthe inoh stendard conceve dies and punches were eet on the teblet mechlne. The teblet weight was adjuated to 450 mgms. by hend-turning mechine when loaded with 16 mesh granules. Preseure rollor settings and weight control cettings were not changed during the compreasion of the other two granulations. The tableting rate wes kept constent of 582 teb./ain, durlng the compreesion of all three granuletions. To deterwine the tableting rate, tablets produced during one alnute of operation were collected and counted and the count was repeated three times.

Sanples of the tablets uaed to study the welght and welght varlation were collected as followe: ten aamples

\footnotetext{
Artbur Colton Company, 3529 E. Iafeyette Are., Detrolt, M1ch.
} 
of ten tablet each were collected during the run of tablet machine. Erch tablet was welghed individusliy and the average eight of each group was caloulated.

Tableting Rate Experfeente. The effect of speed of compresition on tablet weight varietion of the three different sige of granulation as determined.

\section{Copmerestion of $16 \mathrm{Mech}$ Granulas. The granules} pessing through \#16 and retained on \#20 were lubriceted with $0.5 \%$ magnesium stearate. The standard concave $3 / 8$ " dies and punches were used for this compression, and the welght of teblet wa adjusted to 400 mgms. by hand-turning the mochine. The tablete were compreased at flve different mechine opeeda:

The tobleting retes were increased graduelly and evenly by roteting the speed control wheel six full rotetions each time in olookwise direction. Tablets produced during three 1-minute intervale were counted and the average speed of compresalon wa computed from the three counts.

Compreselon of 20 Noch Grenules. Grenules passing through \& \#20 and reteined on 8 \#40 sieve were lubricated 
as before. The tablet weight was adjusted to $450 \mathrm{mgms}$, by band-turning the machine, and the tablets were compreased, using exactly the same aettings of machine as for the \#16 mesh granules. Samples were collected exactly as above.

Effect of Dis S1ze. To deteraine the effect of die size on tablet velght, the granules, prepared as described, passing through \#20 mesh sleve and retained on \#40 mesh were used. The two different die siges and punchee were used $\left(3 / 8^{\prime \prime}\right.$ and $\left.3 / 16^{\prime \prime}\right)$.

$$
\text { Pixst, 3/8" dies were set on tablet press and the }
$$
\#20 megh lubricated granules, were compresed into tablets at two different apeeds. Speod of compreasion was determined by counting the number of tablets produced in one minute (each three times) and then determining the average. Three amples were collected at each opeed and the arerage weight was determined by calculation from the welght of the Indiriduel tablets.

8imilarly, 3/26" dies were set on tablet press and ane \#20 mesh granules were compressed at three different apeeds and aamples were collected as before, and percentage of waight variation was determined at each speed of compreselon.

C. Granule and Bulk Denalty Experiments

Preparation of Grenules. For the preparation of 
granules, the followlng Ingredionte vere used

Lectose U.S.P. Melinorodt 6.91R

BIgunth eubearbonate U.8.P. Amend Drus Co.

Gelatin U.S.R.

Method of Varietion of Denalty of Granules. The denelty of the basic lactose srenulation was increased by the adition of blanuth aubcarbonate in concentrations of 10\%, 20\%, 30\%, and 40\%. Tabl. I g1ves the actual formulas used to prepare each of these granulations.

Preperation of the Binder Solution. Geletin bind- solution was prepared by covering $10 \mathrm{gma}$. of gelatin v.S.P. W1th $40 \mathrm{~m}$ of weter and allowing the mixture to etand unt1l the gelatin became hydreted. The mixture was then beated gentiy with frequent agttetion unt1l the gelatin was disolved. A sufflolent qunntity of water wes then added to make einal volume measure $100 \mathrm{ml}$.

Mixing. Welghed quantities of lactose and blsmuth subarbonate powdere were placed in a Hobart" mixer, and the dry powders vere mixed to unsformity, for about $3-5$ minutes *

Grenulation. To the uniform mixture of these powders in Hobart mixer warm gelatin solution was added

"gobart Mrg. Co., Troy, Ob10 


\section{TABLE I}

GRANULATION PORMULAS

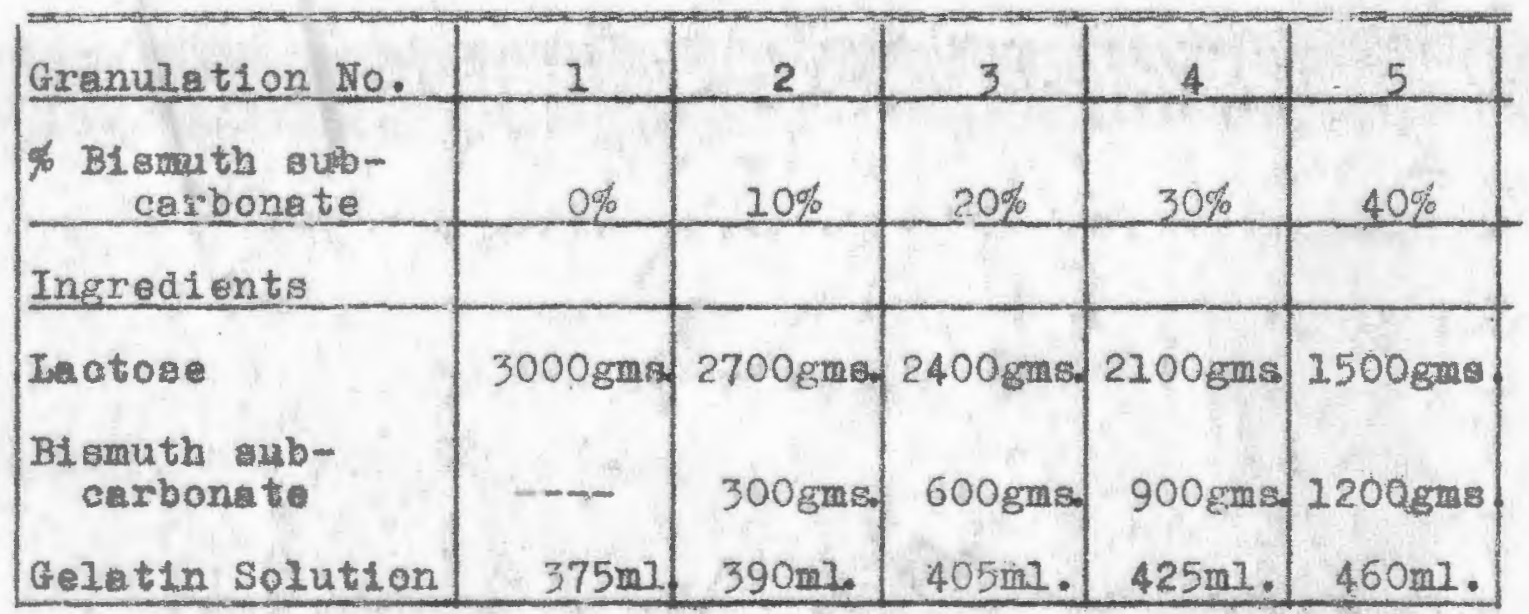


gradually, while mixer was rotating, and the ing edients mixed unt1l the mose read1ly cohered to a ball but equally read1Iy broke up when rubbed between the flngers. This damp mase was then taken out of the mixer end granulated with an Frweke wet granulator. The wet granules were collected on brown paper, put on trays, and dried in an oven at $70^{\circ}$ for four hours.

Supretion into Sige Prections. The dried granules were then reduoed to andler alze by hand forcling them firet through U. S. Sieve \#20 and then through a $\#$ 16. The ranules passed through the \#16 sieve and were retained on a. 20 aiere.

\section{Deteringtion of the Pertingnt Characterietice of the}

\section{Granulat1ons}

\section{S1ze Distribution Determination. A stereo micro-} acope with a callbrated eyeplece and having nagnification of twenty times and fired focal length wes used to determine olze distribution of the sranules. One thousand part1cles of granulea were counted from each lot of granulation. The "nean I1near intercept" (1) method was uged for the measurement of the granules. In this method the mean length of a line intercept by the proflle boundary which approximately bisects the area of the granule proflle is taken as the diameter of the granule. The bisecting 
Iine is taken paraliel to fixed atrection, Irroapective to the orlentation of each particle. Thi has the effect of erolding bias as to the direction in wich the profliea obserred are bleected. Fon this method of dianeter count, reproduclble eraphe for average alse dietribution wero obtalned.

Buik Denetty Deterrinstione. For the deteralnation of bulk density of granuree, the wetbod sugeseted by Butlor, Raneey. and Nartin (13) wo used. A sample of about 50cc. of the sised grenules we cerefuliy introduced into a $2000 \mathrm{c}$ sretuated eylinder. The oylinder was then fropped onto a hard wood aurface (table top) three tiwed from a beligh of about one inob at epproxlmately two second Intervala. BuIk aene1ty was then deterained by dividing the welght of the sample of grenule in grams by the I1nal rolue in co. of the eample contained in the oylinder.

Qranuie Density Deterninstione. A Eercury a1spleocment method alallar to the nethod euggeeted by Striokiand, Buse and Higuob1 (6) was uted to deternine granule dens1 ty.

Plgure I ahowe alagrem of apparetus and ascobly uoed to determine doneity of the exanulea. We internal roluae of the glase bulb (1abeled "A" in diagran) was determined by calouletions fron the welgbed quantlty of wero- 

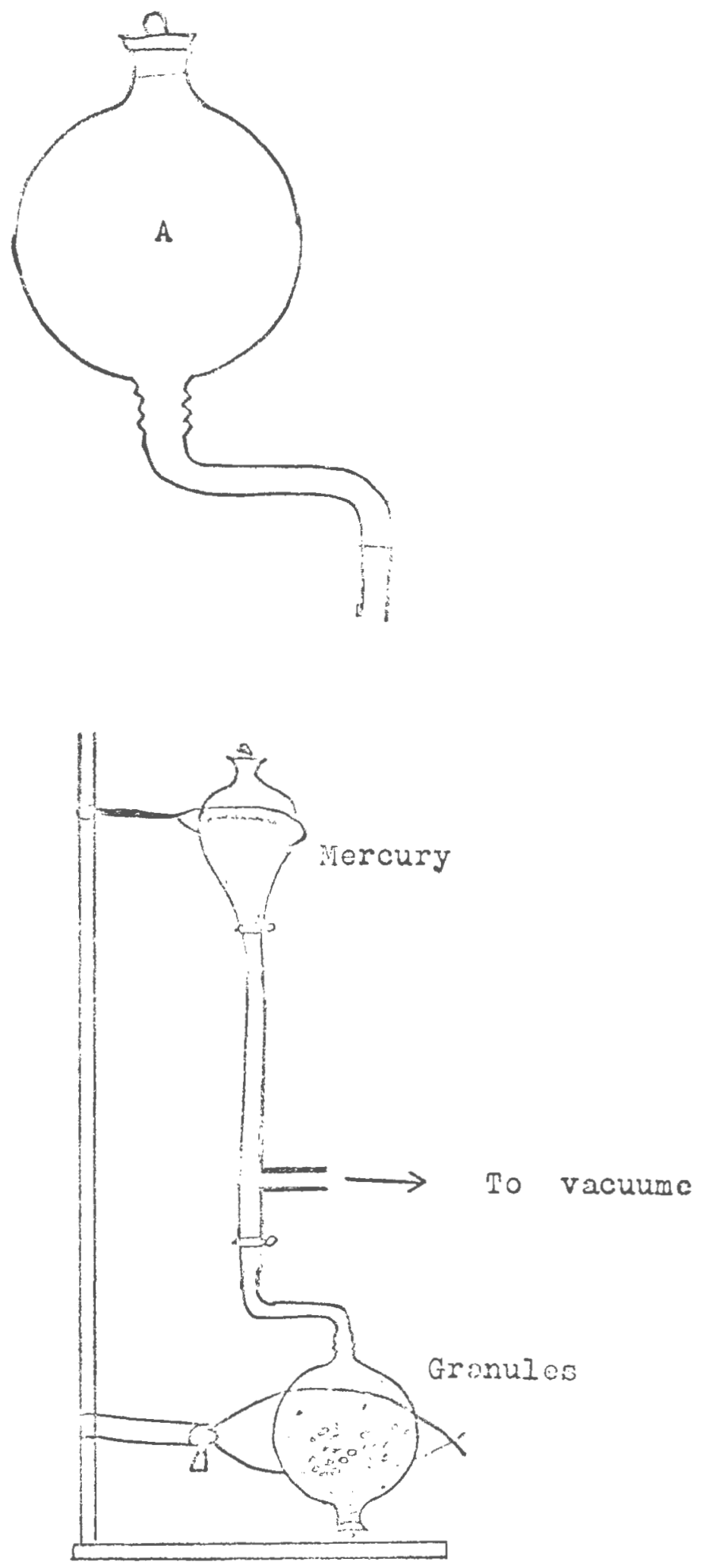

Figure 1 Apparatus to determine Gronule Density. 
ury required to f1ll the bulb to the calibration mark. Grenule density wa determined by plactng a known weight of granules in the expty bulb, pumping the als out of the bulb with vacuum pump, allowing ancoury to flow in to the bulb to the callbretion wark. The bulb containing the mereury and the granules was then romoved from the assembly and weighed. From the known weight of the buIb and the granules and the calibrated volume of bulb, the volume displaced by granules was calculated. The granule density was then caloulated by dividing the welght of granules by the volume displaced.

\section{E. Compresetion of Gronules}

Equipment. A Colton Model 216 rotery tablet mochino was used for all tablet compreasion.

\section{Belection of operating parametere. From the pro-} liminary experimentation some working parameters or condItfons were set up for the study of the effects of granule and bulk density on tablet weight variation. In the first place, the No. 16 granulation were selected because the \$o. 16 granules were the only ones thet could be prepared with afficient yleld from the formulas containing the larger proportions of blamutb subcarbonate. The one-fourth inch dies and atandard concare punch- 
e were used for tablet compreasion. The welght of tablet was adjusted 100 mgma. Wth the lactore granulotion wh1le turning the machine by band. The other 'stendard' settinge of the mech1ne, whlob were kept oonetent during compression of all granulations, were: speod of mochine or tableting rate $(650 \mathrm{tab} / \mathrm{ain})$; overload preseure adjutaente; and flow of gramules through hopper.

Irboricet1on. All granulation were lubricated wh $0.5 \%$ megnesium etearete; $5 \%$ comatarob powder was added during lubriceting a a disintegrating egent.

\section{Detertination. of Iablet Cunnoterietion}

Welcht. As the tablete were belng produced from the meobine fire sapples of twenty-fire tablets each were collected in aeparate boxes, during the compreselon of the different granulation (1,e. granule contelning 10\%, 20\%, $30 \%$ and $40 \%$ blauuth abcerbonate). Dach tablet in a group was weighed individually and the arerage weight, mean deviation, and tandard deriatione were calculated.

S1ze. Thickness and diameter of each of f1fty tablets in ench croup were meacured and the average of thicknese and diemeter was determined.

Heranese. A Pliser* hardnoes toster was used.

* Ptizer, Chen. Sulee Dlr. Chae. P. Plizer Co., Ino. 630 Gluebing AFe., BrootIyA, D.Y. U.S.Pat. 2975630 
Trenty tableto selected at random from eech lot of tablets produced, were tested for hardness, and the average hardness was determined for each lot of tablets.

Disintegretion Tiae. The U.S.P. method* (basketraok asambly) was used. One tablet of the sample from the lot of tablets wa pleced In each of the $1 x$ tubes of the besket and the apparatue was operated, using dist11led water at $37^{\circ}$ as the imersion fluld. The time required for the complete disintegretion of each tablet was noted and the arerage of $81 x$ readings was determined.

\footnotetext{
*.S.P. D1sintegrator. Sclentific GIase Apparatus Do., Ino.
} 


\section{IV}

RESULIS AND DISCUSSION

\section{PRELIMINARY EXPERIMENTS}

\section{Granule Charecteristicg}

The lactose granulations obtained in the elrat part of the experiment were pure wite. As mentioned before, In this series of prelininary experinenta, granule aize was controlled by pasage through U. S. Standard Siever Nos. 16,20 and 40 . Detalled studies on these granules wth regard to g1ze distribution, bulk deneity, and granule density were not carried out.

\section{Efrect of Grenule Siee}

From Table II, which shows the Influence of three different glzes (1.e. Hos. 16, 20 and 40) of granules on tablet wolght and welght rarlation, $1^{t}$ can be coen that the tablet welght incressed a granule gize decreased, and that the welght rariation decreased with decreasing granule s1ze. These results correapond to those obtained by Arambulo and Deardorff (5) who studied the effects of granule size fron sleve HOB. 4 to 170. Arambulo and Deardorfe ettributed the increasing welght with decreasing granule size to a decrease in vold space. They reagoned that large granule gave large proportions of rold sepee 
TABLE II

TABLET WEIGRT AID COBPPIOIENT OP VARIATION OBRAINED FROX 3 DIPYEREMT SIZES OP GRARULATIOHS

\begin{tabular}{|c|c|c|c|}
\hline \multirow{12}{*}{ 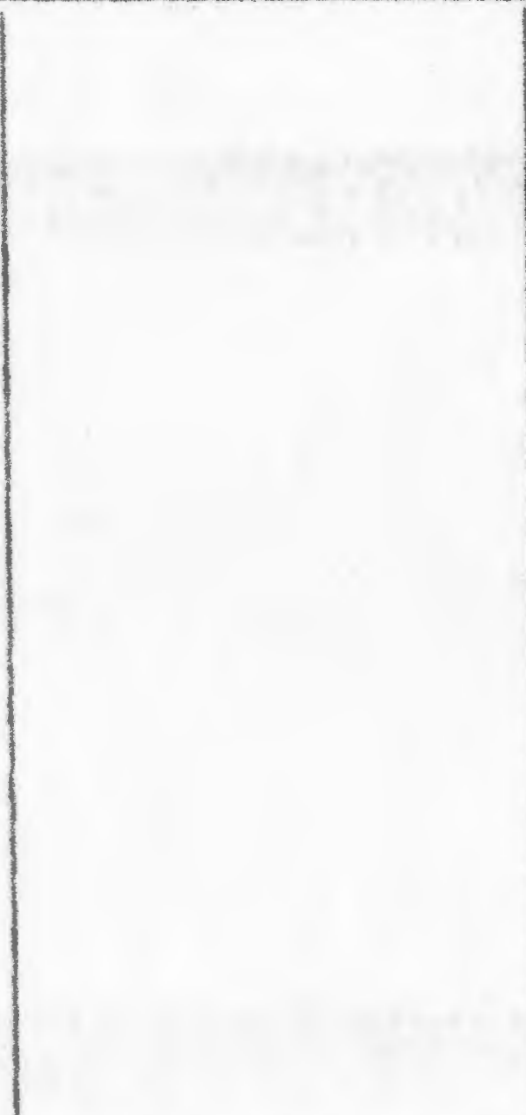 } & \multicolumn{3}{|c|}{$\begin{array}{l}\text { Tablet Welght in MB. From } \\
\text { Crenuletion }\end{array}$} \\
\hline & $26 \mathrm{Meah}$ & $20 \mathrm{Mesh}$ & $40 \mathrm{Meeh}$ \\
\hline & 424 & 482 & 508 \\
\hline & 444 & 485 & 507 \\
\hline & 448 & 478 & 509 \\
\hline & 439 & 503 & 512 \\
\hline & 450 & 508 & 520 \\
\hline & 426 & 497 & 524 \\
\hline & 449 & 490 & 519 \\
\hline & 461 & 499 & 521 \\
\hline & 421 & 493 & 518 \\
\hline & 431 & 482 & 522 \\
\hline Arerage of teb. & 439.3 & 491.7 & 516 \\
\hline Max. Dertetion & 21.7 & 16.3 & 9 \\
\hline Coef. of Varlation & 0.08 & 0.05 & 0.03 \\
\hline
\end{tabular}


In the die before compreselon, reaulting in relatively 11ght welght tablets. As the granule sise was reduced, rold apece was reduced and the average tablet welght increased.

\section{Effect of Tableting Rate}

As show in Table III and Mgure 2, the average tablet weight decreaged a the tableting rate was increased. This trend followed in both olzes of granules uaed. As the tableting rate was increased, there was less t1me for granules to flow into the ale carlty from the feed shoe. In addition, there we tendency for the granules to be thrown outward at higher rotational speeds. In the case of the No. 16 granulations, at the mexireum rate of tableting $22.4 \%$ drop in the average weight of teblets was obeerved, Indlcating el ther that the die car1ties were incompletely fliled by the gramules or that granules were being throw out of the dies by contrifugal force. The latter factor would seem to be less important then the former in view of the later experiments which showed thet, as die alze wa decreased the weight rariation of tablets was increased. In general, as the speed of comprasaion was increaed the weight of the tablets produod was decreased, the variation in welght from the everage tablet velght was also found to increase a the 
TABLE III

AV RAGE HEIGHT OP TABLETS IFROM NO. 26 AMD HO. 20 SIEVE GRAMULES OBFAIUED AT DIFPERENT SPE DS

\begin{tabular}{|c|c|c|c|c|c|}
\hline \multirow[b]{2}{*}{$\mathrm{Tab} / \mathrm{min}$} & \multicolumn{2}{|c|}{$\begin{array}{l}\text { Compression of } \\
\text { 16 Steve Granules }\end{array}$} & \multicolumn{3}{|c|}{ Io. 20 aleve Granules" } \\
\hline & Av. Wt. mg. & $\begin{array}{c}\text { Coef. of } \\
\text { variation }\end{array}$ & $\mathrm{Tab} / \mathrm{min}$ & Av. Wt. ng. & $\begin{array}{l}\text { Coef. } \\
\text { Variation }\end{array}$ \\
\hline 392 & 376.6 & 0.16 & - & - & - \\
\hline 508 & 375 & 0.19 & 580 & 438.0 & 0.11 \\
\hline 632 & 374.2 & 0.20 & 724 & 428.0 & 0.12 \\
\hline 768 & 370 & 0.25 & 912 & 409.3 & 0.14 \\
\hline 932 & 345 & 0.38 & 1020 & 373.0 & 0.21 \\
\hline 1180 & 290 & 0.46 & 1132 & 344.8 & 0.29 \\
\hline
\end{tabular}

"hand turned wolght $400 \mathrm{mg}$. "Whend turned welght $450 \mathrm{mg}$. 
tabloting rate was increased. Phese result are ahom in Table III ead 3gures 2 and 3. As a reoult of 1ncomplete 1111 at hieher epeed of conpreation a drop in the hardnesb of teblets vas also observed. These reaul ts do not parallel those of Heengew tho atudied velght variation at two rates of tableting -42 and 76 tab/atn, and concluded the elgniflosnt difference in tablet welght variation did not remult 76 and $42 \mathrm{tab} / \mathrm{min}$ tebleting reten. The difforence between his reoult and the result: reported here can probably be explataed by the fact thet hasegaw ueed tobleting ratee of 76 and 42 teb/min which are very 10w compared to the $392-1180$ tob/tutn rete uepd in thee experiment. In edation Hacogawi laed a

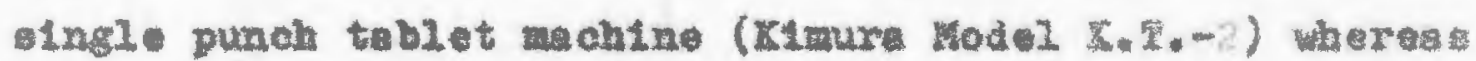
result reported here are from colton 2400101216 ratary tablet machlne.

\section{Sefect of Dle s1ze. (Dlaneter)}

The effect of two different die laets on welght variation at different apeods of compreasion is shown in Teble IV. In the ose of the maller die diameter the coefrictent of variation in higher and in the cese of the lerger d1 diameter, the coeficient of variation 1. less than former. The effect of ale size on weight voristion of the tableta 10 sinilar to deta reported by Hasegawa. The reason for this type of effeot is that larger die 


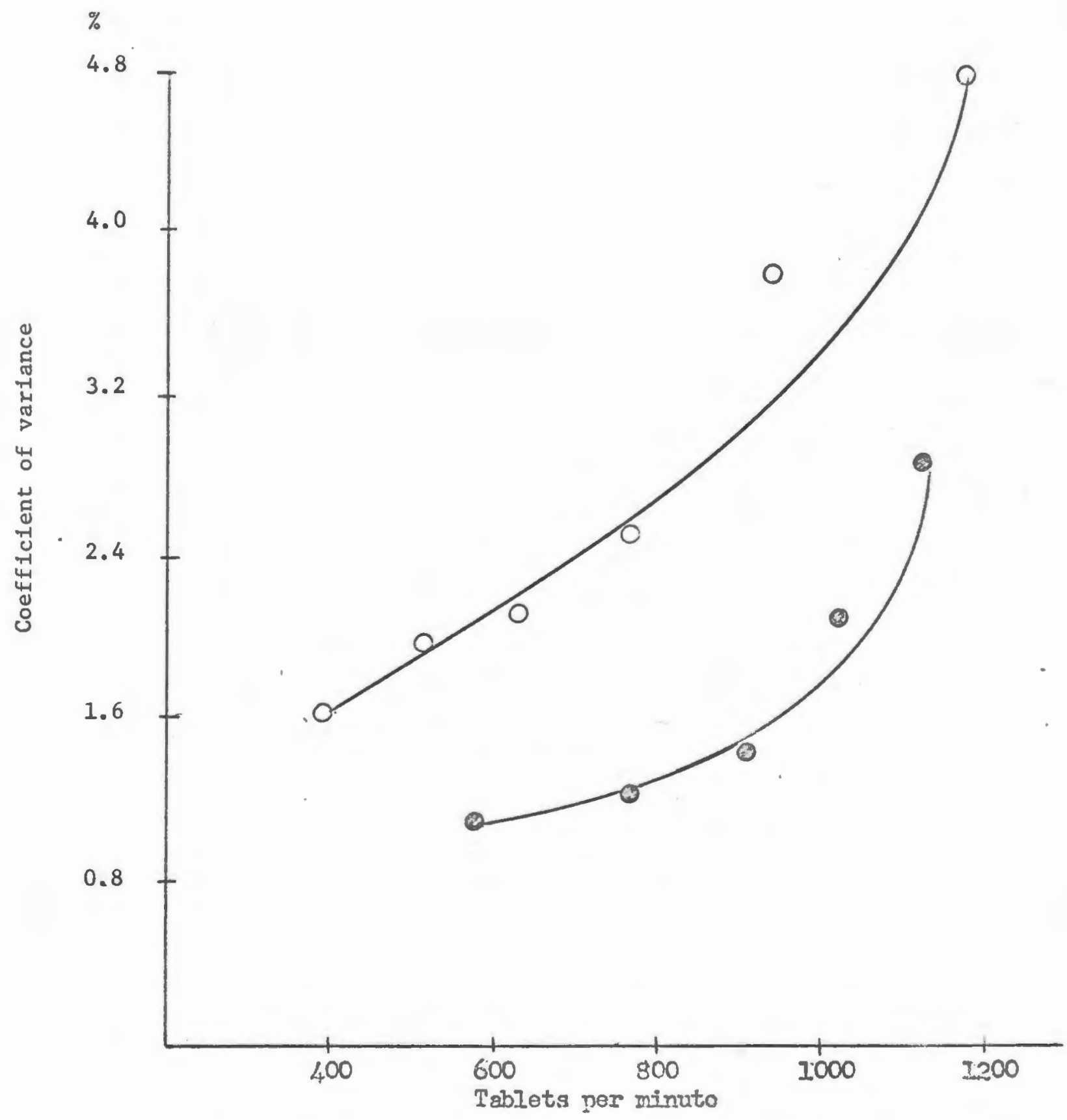

Figure 2 Effect of tableting rate on coefficient of variance. Tablets from No. 20 sieve granules. O Tablets from No. 16 sleve gramies. 


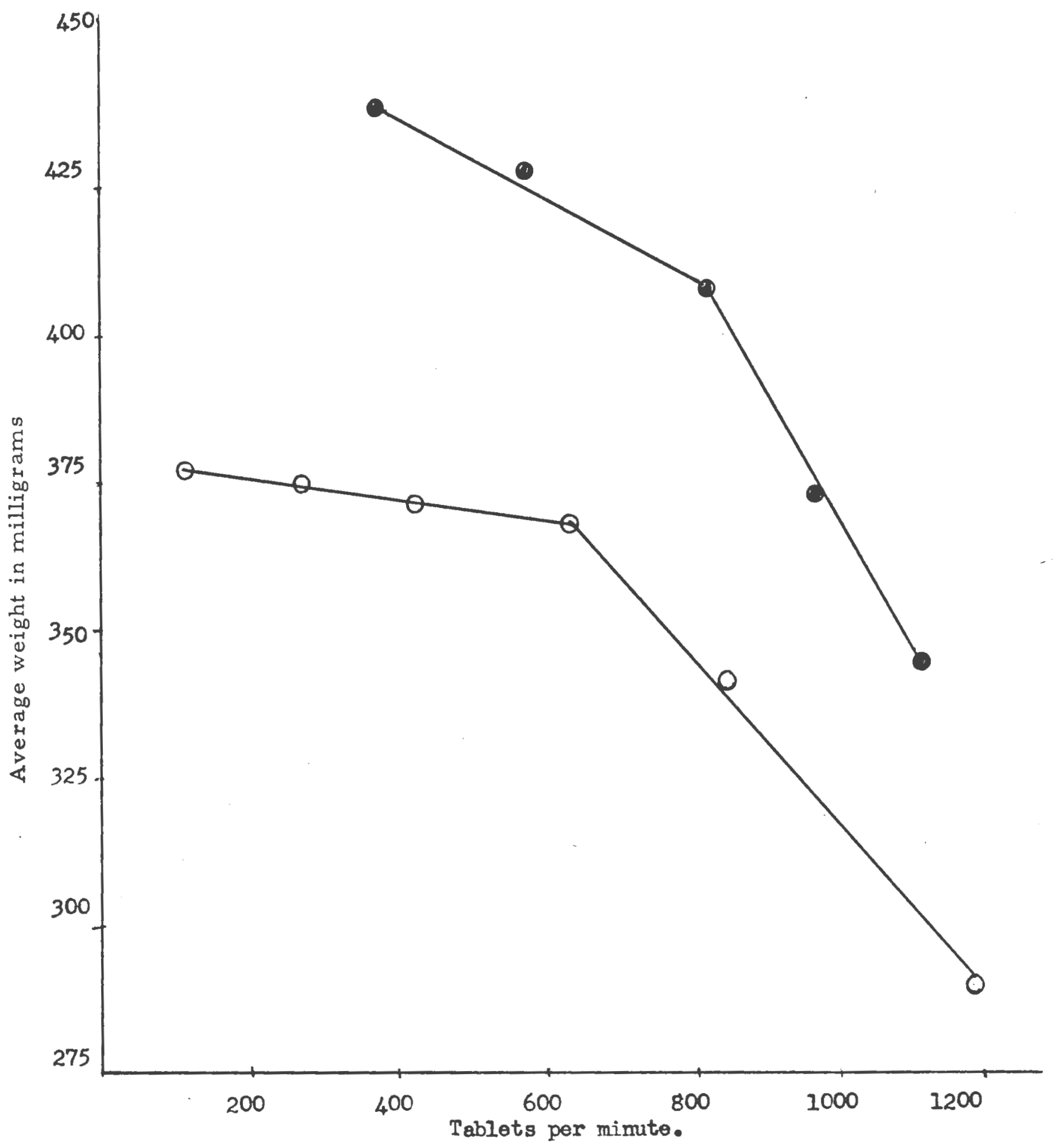

Figure 3 Effect of tableting rate on average welght of tablets.

- Tablets from NO. 20 sieve grenules.

O Tablets from HO, 16 sieve gramules. 
caritle are easier to f1Il and 111 evenly during the run of the tablet mechine than meller die cevities.

\author{
INTEERELATIONSHIP OP GRANULE DENSITY, \\ BULK DENSITY, TABLET WEIGHT AMD \\ WEIGHT VARIATION
}

\title{
Character1stice of Granulation
}

S1se Dietribution. In these tudies the granule alze was controlled within a nerrow range and lze diatribution dat were obteined to show this diatribution. Tables $V$ and VI show the alze distribution of the granu1etions. In Pable $V$ only the Ho. 16 plain lactose granulation we considered, and four counts each of 1,000 granule were made to obtein the plain lactove alze diatribution plota. The average diameter of the granule in m.II. and the standard deviation in each count show thet the results ore very close. The reproduclbillty of these rosults is also shown by the otanderd error which is $1.35 \pm 0.01$. Table VI showe the e1se dietribution of lootose granulation contalning variou concentratione (10\%, 20\%, 30\%, 40\%) of bienuth subcerbonte, compared with plain lactose granulatione. It can be seen frow these date that all the granulatione had aldiar alotributions, but the granulations containing $30 \%$ and $40 \%$ biamuth subcarbonate apparantly contalned al1ghtly bigher proportione 
TABLE IV

EFPECT OF DIE BITE - AVRACE WEICAT AND COEPFICIERT OF VARIANCE OF TABLETS

\begin{tabular}{|c|c|c|c|c|c|}
\hline \multicolumn{3}{|c|}{ D1e $31203 / 8^{n}$} & \multicolumn{3}{|c|}{$D 1 \cdot 812 \cdot 3 / 16$} \\
\hline $1 \mathrm{ab} / \mathrm{min}$ & Av. Wt. $\mathrm{Mg}$ & $\begin{array}{l}\text { Coef. of } \\
\text { Verlence }\end{array}$ & $\mathrm{Tab} / \mathrm{min}$ & Av. Wt. $\mathrm{Mg}$ & $\begin{array}{l}\text { Coof. of } \\
\text { Vertance }\end{array}$ \\
\hline & & & 912 & 153 & 0.061 \\
\hline 980 & 417.0 & 0.05 & 1020 & 140.3 & 0.092 \\
\hline 1130 & 396.0 & 0.10 & 1132 & 127.0 & 0.16 \\
\hline
\end{tabular}




\section{TABIE Y}

PLAIN LACTOSE GRANULATION \#16 MESH DIAMETEF COUHT

\begin{tabular}{|c|c|c|c|c|c|c|c|c|c|c|c|c|c|c|c|c|c|c|}
\hline $\begin{array}{l}\text { Size } \\
\text { in } \\
\text { m. m. }\end{array}$ & 1.9 & 1 & 1.1 & 1.2 & 1.3 & 1.4 & 1.5 & 1.6 & 1.7 & 1.8 & 1.9 & 2 & 2.1 & 2.2 & 2.3 & $\begin{array}{l}\text { Total } \\
\text { Pax- } \\
\text { tieles }\end{array}$ & $\begin{array}{l}\text { Average } \\
\text { Diameter }\end{array}$ & $\begin{array}{l}\text { Standard } \\
\text { Deviation }\end{array}$ \\
\hline $\begin{array}{l}\text { Count } \\
\text { No. }\end{array}$ & & & & & & & & & & & & & & & & & & \\
\hline 1 & 14 & 42 & 107 & 133 & 226 & 248 & 137) & 80 & 48 & 30 & 14 & 10 & 6 & 3 & 2 & 1,000 & 1.37 & 0.228 \\
\hline 2 & 14 & 41 & 121 & 136 & 228 & 149 & 130 & 74 & 46 & 29 & 13 & 10 & 4 & 2 & 0 & 1,000 & 1.36 & C. 222 \\
\hline 3 & 12 & 60 & 105 & 143 & 208 & 141 & 231 & 65 & 43 & 27 & 14 & 10 & 7 & 5 & 3 & 1,000 & 1.36 & 0.229 \\
\hline 4 & 16 & 59 & 121 & 157 & 230 & 150 & 112 & 62 & 41 & 30 & 10 & 6 & 4 & 2 & 0 & 1,000 & 1.34 & 0.222 \\
\hline
\end{tabular}

$\mathrm{SE}=1.35 \pm .01$ 
of granules in the 2.0 to $1.2 \mathrm{~m} . \mathrm{m}$. range, reaulting in a alightly lover average granule elze. Plots of the lize aietributions of the variou granulations are shown in Plgures 4 and 5.

Granule Denaity. Table VII shows that granule density of the ilve different granulation was increased In proportion to the anount of Biamuth subcarbonate added. The granule density ranged from 1.488 for plain lectose granulations to 2.025 for the granules contalning $40 \%$ Bismuth aubcarbonate.

Bull Deneity. The bulk density of the granulation Is relsted to granule density, and wen the density of the basic lactose granulation was increased by the additIon of Blamuth subcerbonate, the bulk denolty of the granules was found almost proportionally incressed (size distribution was oontrolled). Table VII shows the Increase of bulk denelty as the concentration of B1amuth suboarbonate wa increased. If the size diatribution of granules had not been controlled, the bulk density of grenules might have shown different trend, wine bulk dengity is also influenced by shape and alze of granuzes.

Migcellaneous. The granulatione prepared from plin lactose and those prepared by adding various con- 


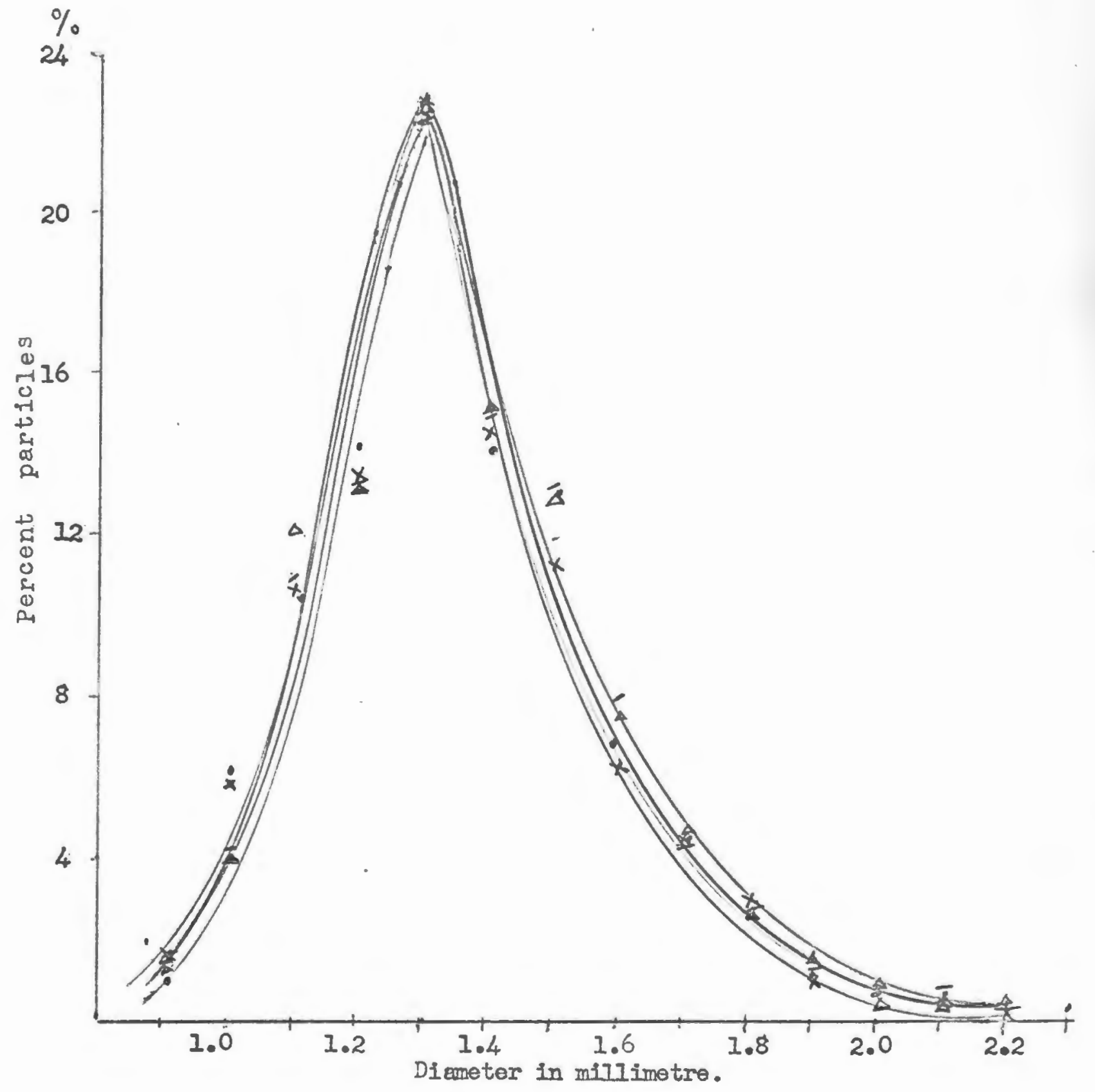

Figure 4 Granule sizo distribution of No. 16 sievo platn lectose granules. 


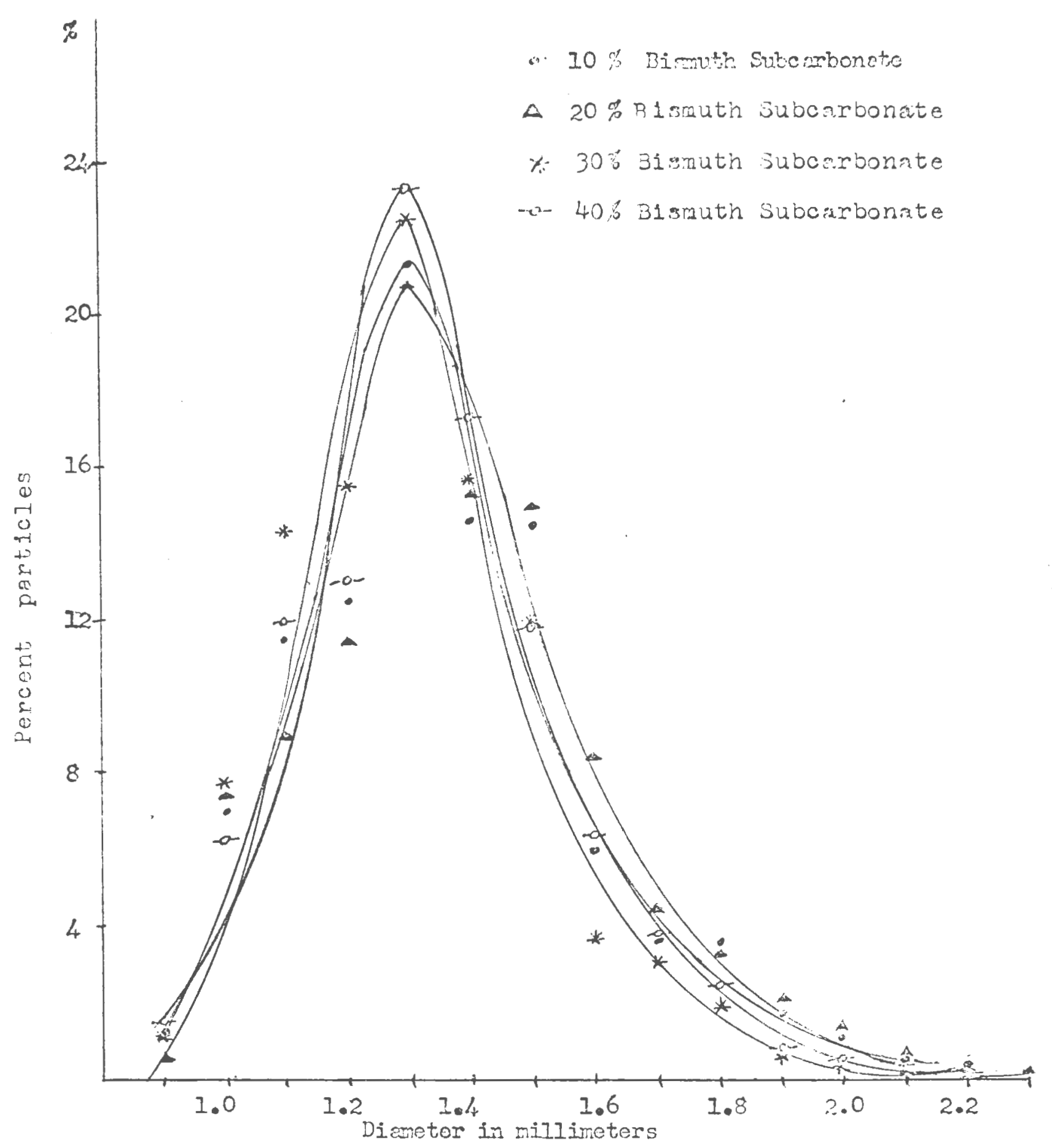

Figuro 5 Granule size distribution of $\% .16$ sieve lictose srenules cartining varions concentretions of Bismuth Subcarbonate. 
PABLE VI

GRANULATION OF IACFOSE AND BISMUTH SUBCARBONATE

PARTICLE DIAMEPER COUNT

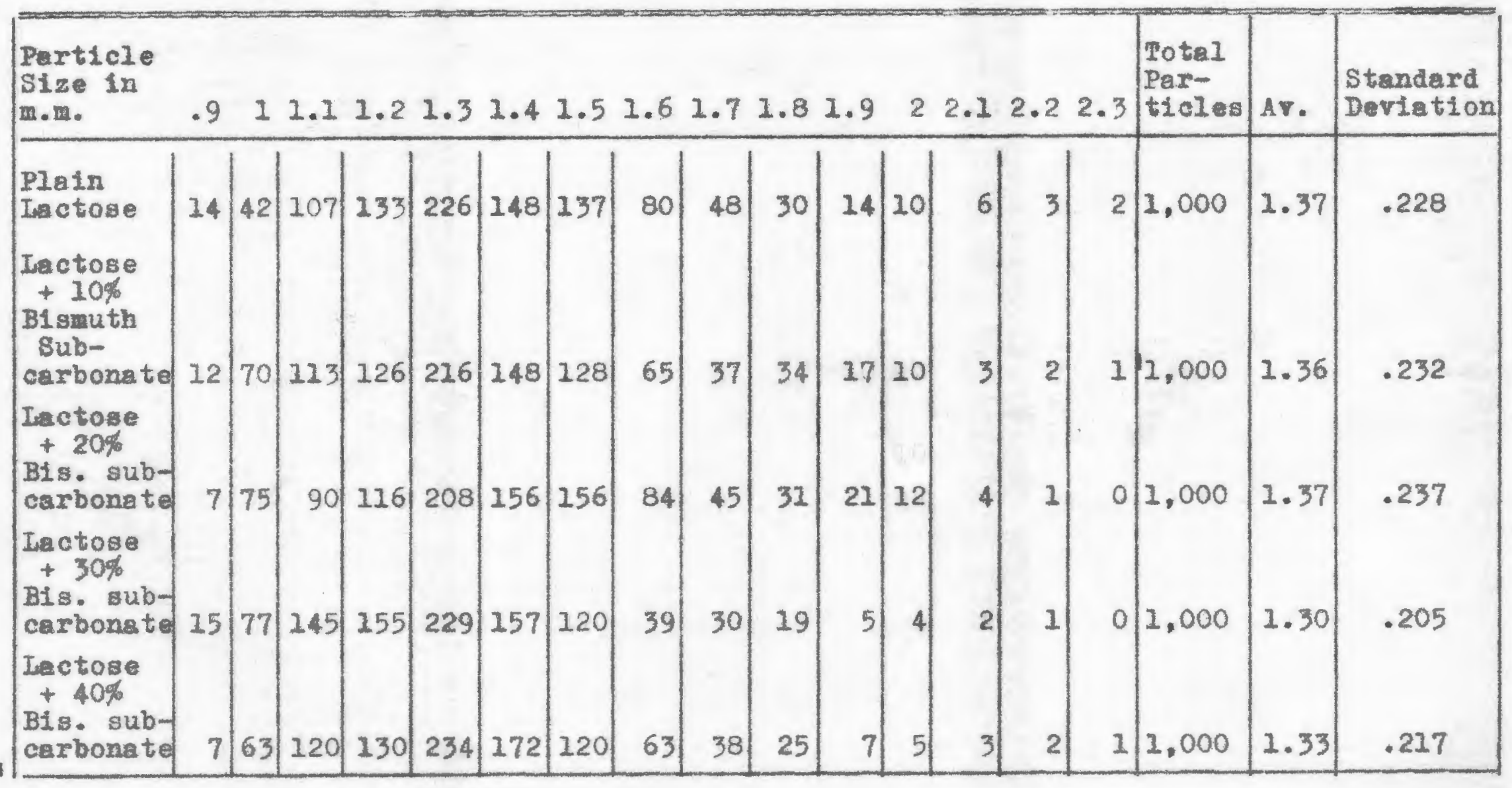


TABLE VII

GRANULE AND BULA DENSITY OF DI PTEEENT GRAITUAATONS

\begin{tabular}{|c|c|c|}
\hline Granulations & $\begin{array}{l}\text { Granule } \\
\text { Density }\end{array}$ & $\begin{array}{l}\text { Butk } \\
\text { Density }\end{array}$ \\
\hline Plain Letose & 1.488 & 0.432 \\
\hline $\begin{array}{l}\text { Lactose }+10 \% \text { Bismuth } \\
\text { subcerbonete }\end{array}$ & 1.564 & 0.483 \\
\hline $\begin{array}{l}\text { Letose }+20 \% \text { Biamuth } \\
\text { abcarbonate }\end{array}$ & 1.653 & 0.497 \\
\hline $\begin{array}{l}\text { Lactoes }+30 \% \text { BIsmuth } \\
\text { subcarbonete }\end{array}$ & 1.81 & 0.582 \\
\hline $\begin{array}{l}\text { Letose }+40 \% \text { Bianutb } \\
\text { aubearbonate }\end{array}$ & 2.02 & 0.683 \\
\hline
\end{tabular}


centrations of blamuth auborbonate ahowed little ohange in gross appearance except with reapect to color. The plain lectose granulation were pure white in color, but a the inereaing proportion of biamutb subcarbonate (1.e. $10 \%, 20 \%, 30 \%$ and $40 \%$ ) were sdded the white color was changed grodully to of white (or pale tan) color. The granulatione conteining biamutb oubearbonate wer barder, poseibly due to the larger amount of binder solution required to prepere the granules. When magnifled, it was obeerved thet the biemuth aubcarbonete granules were sonewhet lose rogular in wape than those of the plain lactoes gramulations.

\section{RELATI NSUIP OF BULK DENSITY \\ TC GEANULE DENSITY}

wen the size and size dietribution of granular perticle are controlled within nerrow limita, veriationo in other physios cbaraoteristles wuch as porouity and wape are reflected by chenges in the granule density and buik density.

Granule density as determined by the mereury displacement method, reflecte changes in intreparticle porosity (due to totally enciosed air pookete, and wicro- 
pores too mall for the mercury to enter at ordinary pressure) and changes in the average true density of the materials used to make up the grenulation. BuIk denotty reflects the change in granule denoity and interparticle vold apees. Since the interparticle rold space is dependent upon the pooking charecteriotic of the granuzat1ons, whape differences in the granulation w11l be reflected by the changes in the bulk density. The matheatioel relationehip as ahow below:

In the mercury displacenent method granule density

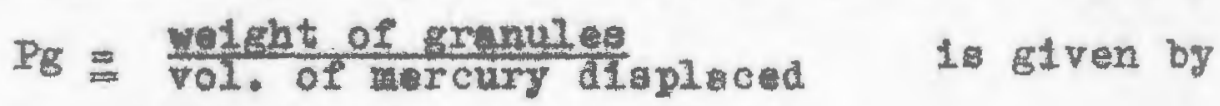
the bulk volume, ho - granule rolume, VG. Now, In the cage of bulk denalty, the mass of the powder 1: divided by Bulk volume ( $\frac{\mathrm{Wg}}{\mathrm{W}}$ ). Bulk rolume includes Vold Porasity which is derined as shown below:

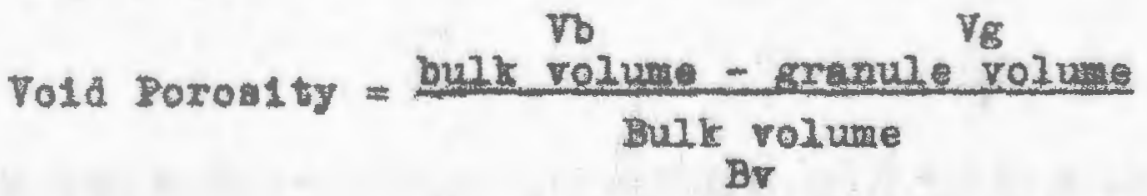

$$
\begin{aligned}
& =1-\frac{\text { weteht/grenule density }}{\text { welght/oult density }} \\
& =1-\frac{\text { Bulk denelty }}{\text { granule density }}
\end{aligned}
$$

From this derivation it can be seen that the bulk volume of granules and therefore bulk deneity 1 s related to granuze density. Now, the vold porosity or inter 
spees can be controlled by oontrolling the sloe and whepe of the granules. And, now if the alze of the granules 1 . controlled and densty of the granules is increased, then, the buix denolty ahould show ohenges parallel to the granule dencities. Higure 9 hows thet this parallel was obtalned experimentally when grenule slze and glze algtribution were very carefully controlzed. A nearly atralght line relationdulp was obtained. As olze distribution date (Mgures 5 and 6) shows, all five granulations had very sinilar sioe distributions. It seems probablo that, for a glven typo of granuletion passing through a No. 16 sieve, the granules would have approximately the same rold speces, and therefore the bulk density would be Increased as the grenul density incressed. The smsil devietion from Iinearity that was observed may have been due elther to all difference in granule shape and consequent ohanges in packing oharacteristic or to the fmall ohanges in sige diatributions seon in Mgures 5 and 6.

\section{INTERRELATIONSHIPS OF TABLET WEIGHT, WEIGHT VARIATION AID GRANULE AND BULR DENSITY}

Table VII show the interrelationship batween granule and bulk density and tablet welght, welght rariation. Tablet welght was seen to inerease Ilnearly, in proportion 


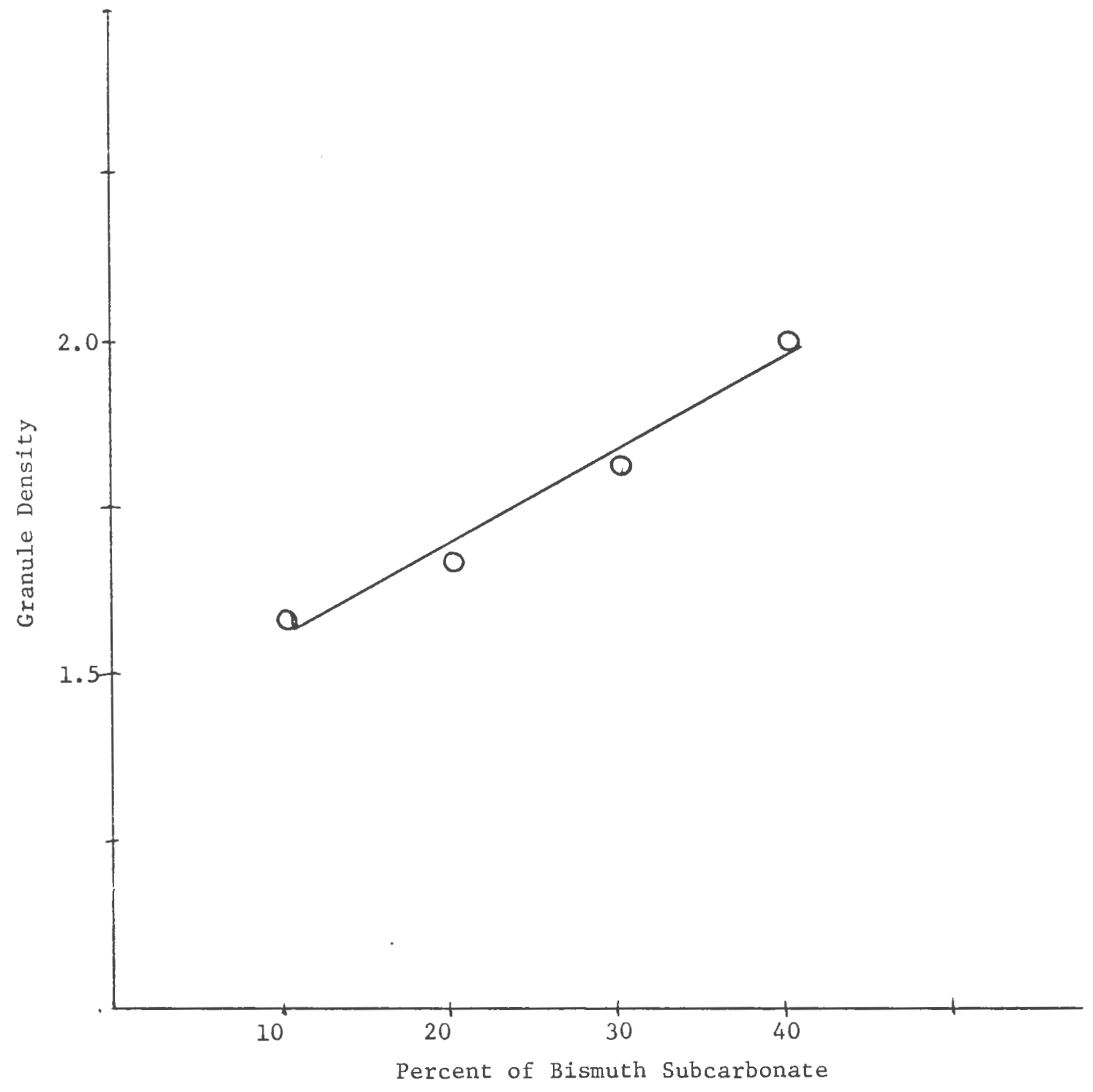

Figure 6 Effect of Bismuth Subcarbonate on Granule Density. 


\section{TABLE VIII}

EFIECTS OF GRANULE AND BULK DINSITY ON

TABLEP WEIGHT AND WEIGH' VARTATION

\begin{tabular}{|c|c|c|c|c|c|c|}
\hline Granulation & $\begin{array}{l}\text { Granule } \\
\text { Denelty }\end{array}$ & Buik & $\begin{array}{l}\text { Average } \\
\text { Welght }\end{array}$ & Meen & $\begin{array}{l}\text { Standard } \\
\text { Deriation }\end{array}$ & $\begin{array}{l}\text { Coef. of } \\
\text { Tarianoe }\end{array}$ \\
\hline Plaln Lactone & 2.488 & .432 & 90.505 & 2.1154 & 2.568 & 0.0284 \\
\hline $\begin{array}{l}\text { Lectose + } 10 \% \text { Blamuth } \\
\text { subcarbonete }\end{array}$ & 1.564 & .483 & 98.637 & 2.127 & 2.627 & 0.026 \\
\hline $\begin{array}{l}\text { Iactose + } 20 \% \text { Biamuth } \\
\text { subcarbonete }\end{array}$ & 1.653 & -497 & 102.65 & 2.0032 & 2.580 & 0.025 \\
\hline $\begin{array}{l}\text { Lactose + } 30 \% \text { Bismuth } \\
\text { subcarbone te }\end{array}$ & 1.81 & .582 & 119.85 & 2.556 & 2.428 & 0.018 \\
\hline $\begin{array}{l}\text { Lactose + } 40 \% \text { Blsmuth } \\
\text { cubcerbonate }\end{array}$ & 2.025 & .6834 & 139.81 & 2.836 & 3.606 & 0.026 \\
\hline
\end{tabular}


to the bulk density change. The relationabip of tablet welght to granul density was somewat more variable (as might be expeoted) but with the granulations used, a fairly cloe reletionohip wa seen. Th1s relationship would be expected to vary wth particle obape, and with pertiele alze and pize distribution. The bulk density of ple1n lactoes granules was 0.432 and the average weight of teblets prepared from theee granules was 90.5 ing., compared to a bulk density 0.683 of lactose +40 bismuth aubcarbonato and en average walght of tablets from the ge granules of 139.8 ag. The coefficient of vartation for plain lactose tablete wa 0.028 , and standerd devietion wa 2.568 , compared to coeffloient of variation 0.026 and standard deviation 3.606 thet of lectose $+40 \%$ b1 amuth aubcarbonste tablets. Thege flgurea mow that bulk denoity of granules affected the average welght and welght variation of the tablete, and that the varietion in welght within g granulation on a relstive basla was practicelly 1dentical. These deta are hown in Pigure 7 in which the tablet arerage wolght la plotted againat granule denaity and in Pigure 8 in whiob tablet sverege weight 1 plotted agelnst buik density. The bulk density of grenules containlug $20 \%$ blemuth auborbonate we found Blithtly lower than that expected. Although the B1se of the eranules was controlled to within narrow range, the 1010 


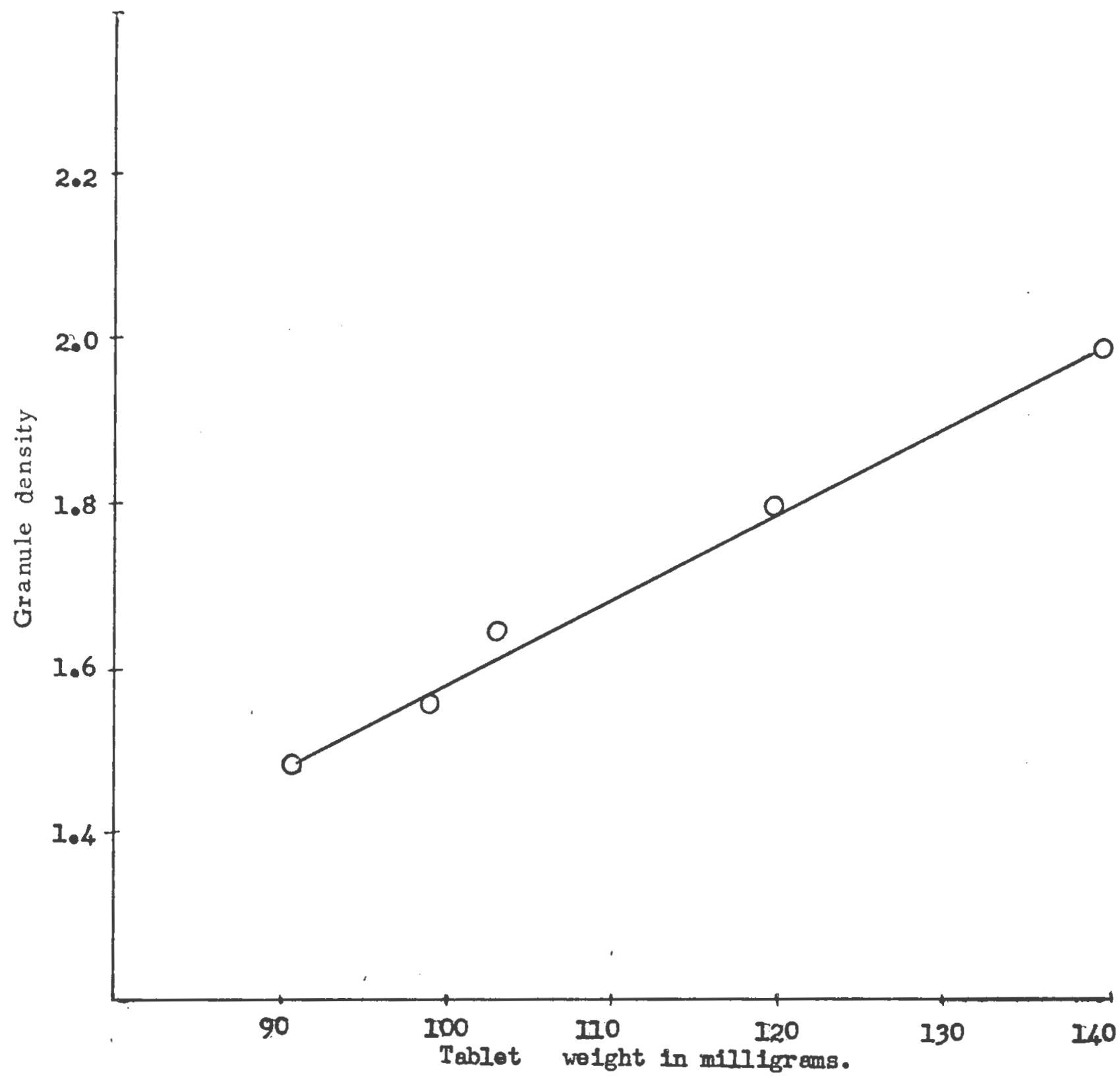

Figure 7 Relationship between granule density and average welght of tablets. 


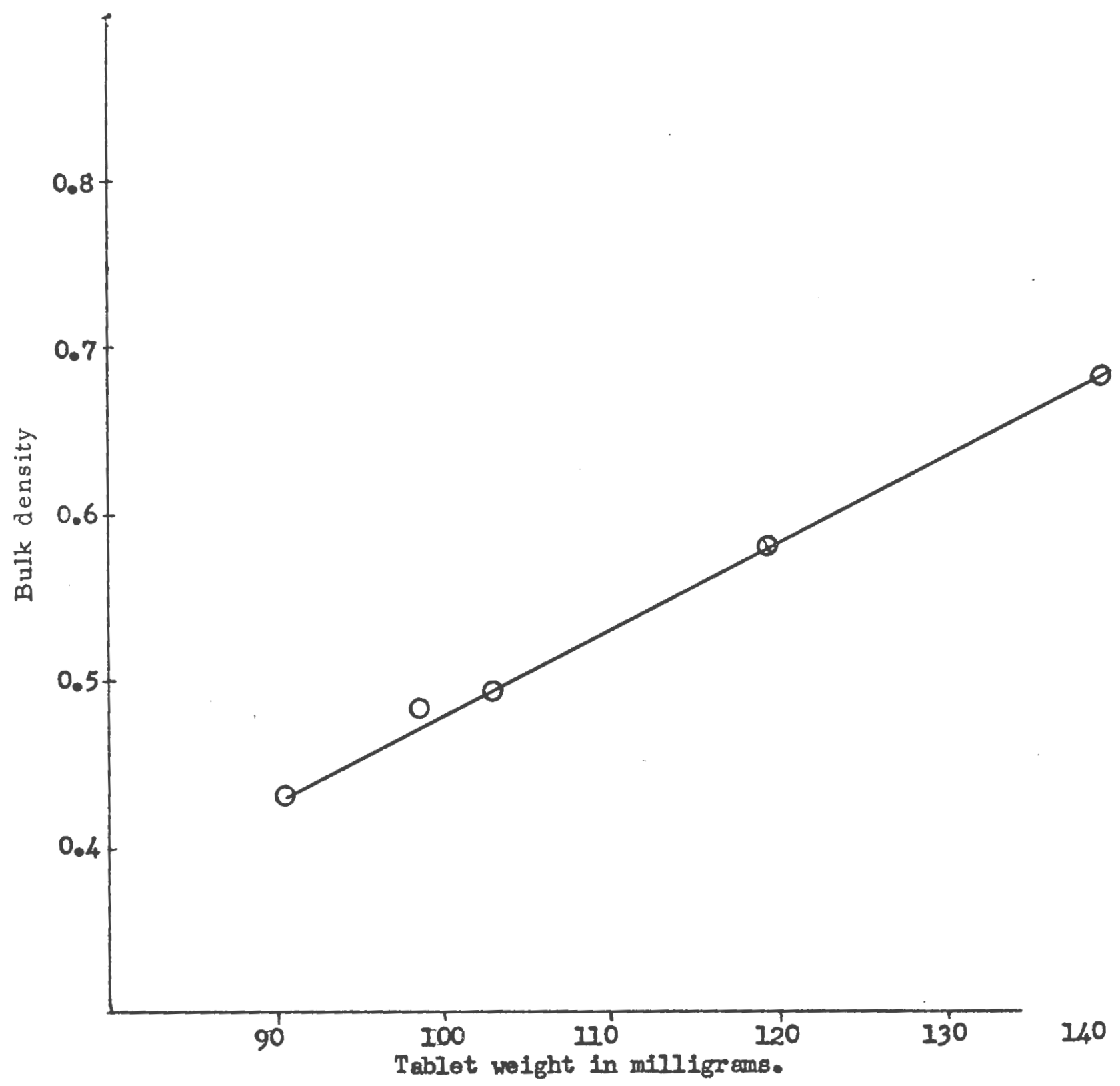

FIgure 8 Relationshlp between bulk density and arerage weight of tablets. 
distribution date (19ures 4 and 5) how a lightig bigher proportion of granules in the 1 - $1.3 \mathrm{~mm}$ region. This variation in diatribution eould have affocted the bulk density of those gramales contalning $20 \%$ blsmuth abourbonate. Another factor affecting the bulk densty, could have been shape of the partlales and their packlag characterist1os. When the shape of different granules were compared under the mioroscope, the platn laotose granules were found to be smooth and round, but those granules contalning blsmuth aubearbonate were a little more 1rregular in wape. The granules contalning $20 \%$ blamuth subcarbonate had the least smooth surfaces. Both the size diatribution and the shape differences could have caused bylk density lower than expected in this granulation.

\section{CHARACTERISTICS OF THE TABLEHS PRODUCED WROM THE DIFTERIAT GRANULATIONS}

The tablets obtained from the plaln lactome granulation ware pure white in color, but the tablets contalnInc blamuth subcerbonate were somewhat off wite in color, the color darkentng as the proportion of the bismuth aubcarbonte was increaged. The hardness of the tablets was found to increase gradually as the percentage of blsmuth subonrbonate added; and therefore, the density of granule 


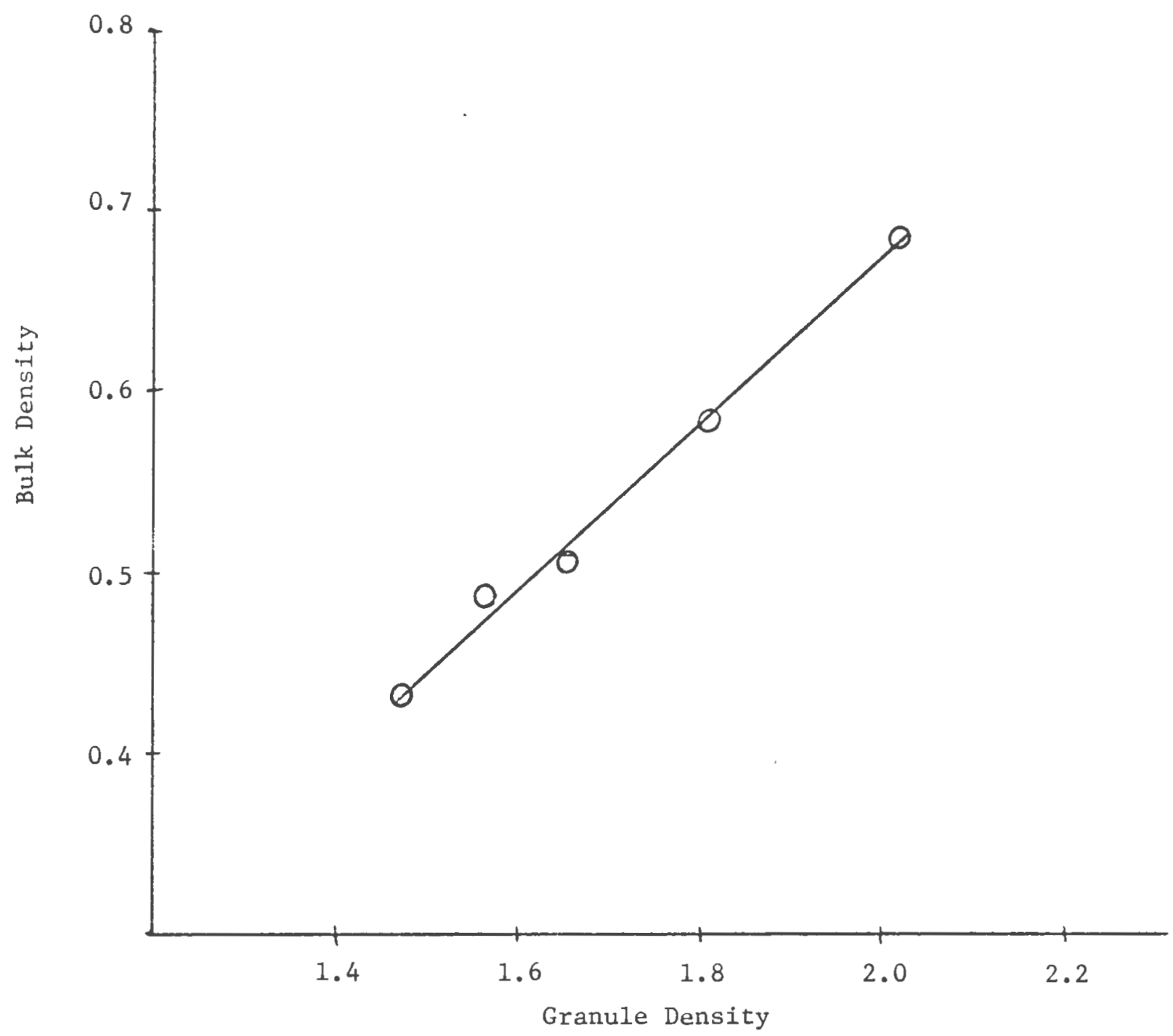

Figure 9 Relationship between Granule Density and Bulk Density. 


\section{PABLE IX}

TABLE SHOWING OTHER DATA ON TABLETS PRODUCED

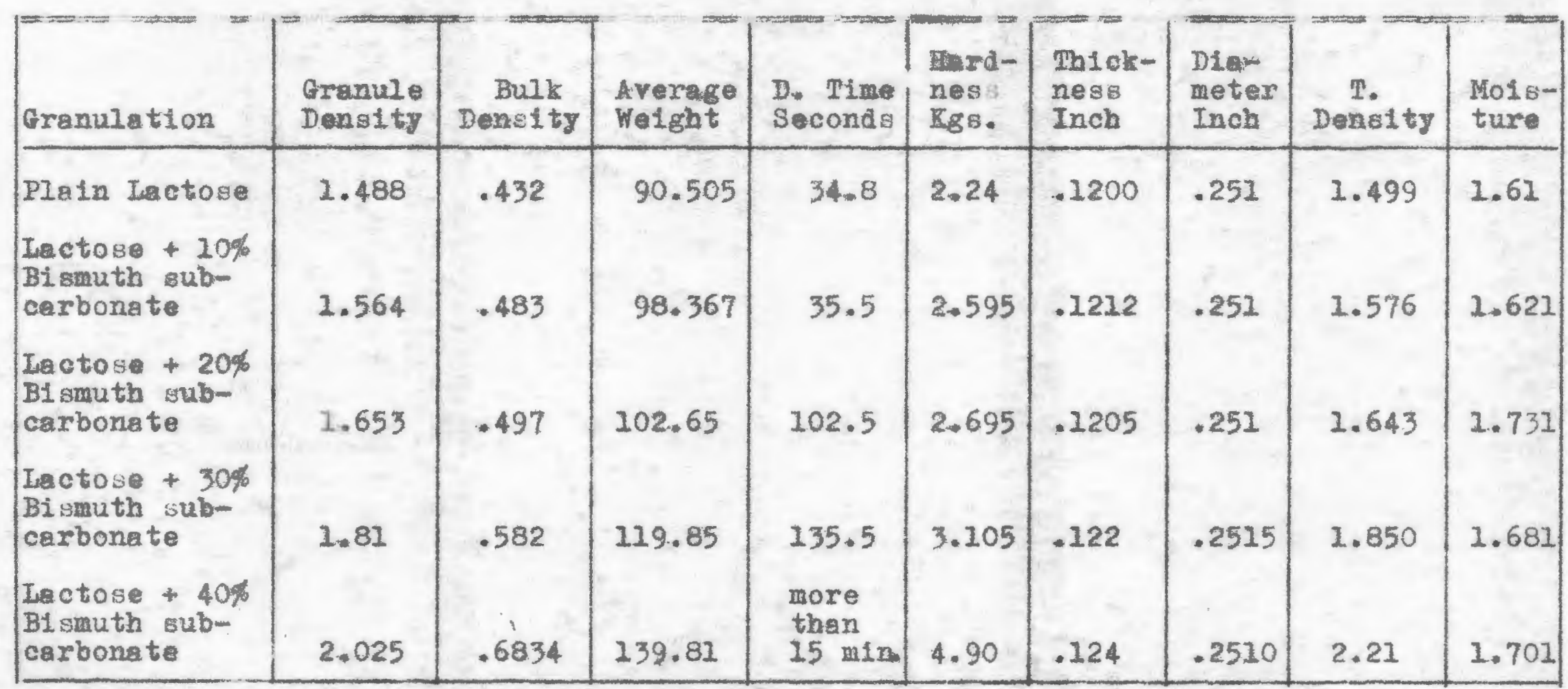


was Increased. This is seen In Table $\frac{\pi}{V I}$ where hardneas of tablet containing only lactove wa $2.24 \mathrm{Kg}$. and hardness of tableta containing $40 \%$ bismuth subcarbonate wes found to be $4.90 \mathrm{Kg}$.

Mals table also comparea the alaintegration time of tablets from five different granulations. It can be seen that the disintegration tine wa gradualiy increased wth the Increasing concentrations of biswuth aubcarbonate. The average aleintegration time of plain leotoce tablet was 34.8 econda and the arerage disintegration time of tablete contelning $40 \%$ blamuth oubcarbonate wa more than 15 minutes, even though $5 \%$ corn staroh was added to each granulation as a disintegrating agent. This gradual increase in alsintegration time was probably due to the increase in hardness of the tablets reeulting in tablet: less read1ly penetrated by water.

The tablet dieneter in 11 kinda of tableta was found to be ldentlcel, but the tablet thlokness was found to be al1 ght1y increased (0.1200 to 0.1249 inch) as the density of the granulations increased. The tablet dens1 ty was found to follow the same trend as ranule density. 


\author{
$\nabla$ \\ SUMMARY AMD CONCLUSIONS
}

1. study of several factor affecting tablet weigbt and weight verlation wes carried out. In preliminery oeries of experiments, lectose granulatione were prepared and effect of grenule ize, peed of compreston, and die diameter vere studied, compressing teblete on a Colton hodel 216 rotary tablea prese. Resulte of these experimente ere found to be oimiler to those reported in the 11tereture. From the data end techniques of these experimenta, some optimun conditions, such os granule s1ze, rate of tableting, die diemeter, etc., ere get up to itudy the effects of granule and bulk denalty on tablet eight snd elght variation. The density of a basic lactose granulation as increased by the addition of various proportions of blamuth suboarbonete (true density 6.36). Bulk and granule density of these gronules was determined. The sie of theae granulotion as controlied to within narro range (No. 16 and No. 20 sleved) and the orerage alze diotribution was deterained by op optical method. All granulation were compressed into toblet on f1ed stondard setting of a Colton Model 216 rotary press and the following conelusions were drawn:

(1) The density of lectose granulation can be 
succosafuly Increased by the addition of rarious proportion of beavy substanoes such as blsmuth mubarbonte.

(2) When granule oise distribution is osefuliy controlled wthin narrow ILIta, bulk and granule denaity are linearly related.

(3) The Increase in the averuge weight of the tabIete wes observed to be a IInear function of the bulk density of the granuletions.

(4) A aldilax relationdip was found to sxiat between granule density and tablet welght, as might be expected.

(5) The incrasse in the granule denalty and in bulk deneity also effected other phyalal properties of tablets such as hardness, thlekrnoss and disintegration time.

(6) The coefrietent of weight rarietion of tablete wibin a granulation wa found to be praetiealig ientical for all the different granulations even though bulk density of the granulatione was varied from 0.432 to 0.6834 . The atandard deviations rarted wth the arerage welght of the tablete produced. 


\section{REFDR ENCES}


1. Martin G. Trifs. Brit. Cer. Sog. 23, 61 (1923-24)

2. Iiverseegel. W. P.: Pharm. J. 116232 (1926)

3. Ewolng, C. 0., Bull, Eint. Formul, Corne 16, 121 (1948)

4. Arambulo, A, Deardorf, D., An. J. Ph. So, 8c. Ed. 42 $690(1953)^{\circ}$

5. I rembulo, A., Hel emes, Deardorf1, D., An. J. Ph. Bo. So. Ed. 42692 (1953)

6. Strlokland, Busse, H1guah1, T. Am. J. Ph. Sc. So. El. 4593 (1953)

7. Smith, G. Herdan, Small Fartiole Stat1otiog. IIseNier Pub. Co. (1953)

8. Aok1, M., Jepan J. Ph. and Open. 26186 (1954)

9. Aor1, M., Pecuda, Japand, Phe and Chen. 75878 (1955)

10. Fief1, A. M., Arambulo, A., Deardorf1, D. Am. J. Fh. Sc. So. LA. 44290 (2955)

11. Aoki, M., Facuda, J. Ph. Soe. Jepen 76140 (1956)

12. Hesegawa, J., Jepan J. Ph. and Ches. 215 (1957)

13. Mart1n, 1. Phreleal Pherngoy. Lea and Foh1ger (1960)

14. Moskalyk, Chatton, Pernarowat1, I, Am. Ph. Aceoc. 50 651 (1961)

15. Makeymilien Burx, J. A. Cer. Soc. 354 (1962)

16. Garret, E., J. An. Ph. Aesoc. 45105 (1965)

17. Snedecor, G. Sthtidticel Method. Iows State Univ. Press, 1965.

18. Cook, Mart1n, Renington's Practice of Pharmaor. 12 th Edition 45 